\title{
Attempts at Preventing Further Spread of Bovine Virus Diarrhoea Virus (BVDV) Infection in 5 Danish Dairy Herds in which BVDV had been Isolated
}

\author{
By H. Houe and V. Palfi
}

Department of Clinical Studies, Division of Large Animal Medicine, The Royal Veterinary and Agricultural University, Frederiksberg, and The National Veterinary Laboratory, Copenhagen, Denmark.

\begin{abstract}
Houe, H. and V. Palfi: Attempts at preventing further spread of bovine virus diarrhoea virus (BVDV) infection in 5 Danish dairy herds in which BVDV had been isolated. Acta vet. scand. 1993, 34, 139-144. - In 5 herds in which bovine virus diarrhoea virus (BVDV) had been isolated, all animals were bled for virological and serological examination. After the herd blood test, follow up blood tests were made on calves born up to 6 months later in 1 herd, 9 months later in 1 herd and up to 12 months later in 3 herds. Persistently infected animals (PI animals) were removed and after a time period a small herd sample of 10 animals that were born after removal of the PI animals were examined for BVDV antibodies.

At the herd blood test a total of 21 PI animals were detected. During the follow up period another 25 PI animals were born.

Among animals in the small herd samples collected after removal of the PI animals, antibody positive animals were found in the 2 herds with the shortest follow up period. In the 3 herds with a 1 year follow up period there were no antibody carriers in the herd sample.

It seems possible to prevent further spread of infection with BVDV if all animals in the herds as well as animals born during the following year are examined and PI animals removed.
\end{abstract}

pestivirus; cattle; control.

\section{Introduction}

Bovine virus diarrhoea virus (BVDV) is widely distributed. Most cattle acquire infection during their first years of life. Postnatal infection is most often subclinical. The major losses due to BVDV infection is caused by foetal infection. During infection of pregnant seronegative animals the virus invades the foetus. Foetal infection may lead to foetal death and abortion, congenital defects, growth retardation and immunotolerance (Done et al. 1980, Roeder et al. 1986). Immunotolerance is induced by infection in the first trimester of pregnancy and leaves the calf with a persistent lifelong infection (McClurkin et al. 1984). Persistently infected animals (PI animals) may later succumb to fatal mucosal disease (Brownlie et al. 1984, Bolin et al. 1985).

PI animals are very important sources of infection (Roeder \& Drew 1984, Roeder et al. 1986, Meyling et al. 1990) as they are continuously excreting virus to the surroundings ( $\mathrm{Co}$ ria \& McClurkin 1978). Herds with PI animals have a high prevalence of antibody carriers compared to herds without PI animals (Houe 
\& Meyling 1991). There may be many other sources for transmission of the infection than direct contact with PI animals: acutely infected animals, infected sheep and goats, semen, embryo transfer, needle transmission, contaminated vaccines and others (Roeder \& Harkness 1986, Meyling et al. 1990, Bolin 1990), but their practical importance has been difficult to assess. Based upon knowledge of incidence of infection, ease of transmission, presence of inapparent infection and non-bovine reservoirs, eradication of BVDV has been considered an untenable task (Roeder \& Harkness 1986).

Along with increased knowledge of incidence of infection and of the damages caused by this virus a greater desire of controlling the infection has emerged. Three different types of general control strategies has been proposed (Harkness 1987): 1. Identification and removal of PI animals, 2. Vaccination and 3. No intervention.

The purpose of this study was to measure spread of infection with BVDV in herds after PI animals had been identified and removed.

\section{Materials and methods}

Selection of herds

Five herds in which BVDV had been isolated were selected for the study. Three herds (Nos. 1-3) were selected after clinical outbreak of BVDV infection whereas 2 herds (Nos. 4-5) were selected after PI animals had been detected in a screening project. In Herds 1 and 2 there had been severe clinical symptoms of acute infection, demonstrated by rise in antibody titers. Further, virus was isolated from abortions in both herds. In Herd 3, BVDV was isolated from a case of mucosal disease. In Herds 4 and 5, 1 and 10 PI animals had been found, respectively. In these 2 herds there had been no clinical signs of infection at the time when the herds were selected.

\section{Blood testing}

Virological examination was performed by an indirect immunoperoxidase technique. Antibody detection was performed by a serum neutralisation test using a Danish cytopathogenic BVDV strain as the test strain (Meyling 1984). In the last part of the study (the spot tests) antibody analysis was performed by an indirect ELISA: microtiter plates were coated with the gp (glycoprotein) $48.000 \mathrm{Ag}$ of NADL BVDV strain. Samples were tested at a dilution of 1:25. As a detector system peroxidase labelled rabbit anti-bovine immunoglobulins and OPD substrate were used ( $Q v i s t$ submitted).

In each herd, all animals were bled for virological and serological examination. In Herd 1 the whole herd was bled 6 months after the acute infection and in Herd 2 the whole herd was bled 1 month after the acute infection. In Herd 3 the whole herd was bled 4 months after an animal had died of mucosal disease.

In Herds 1 and 3, all calves younger than 6 months at the herd blood test were retested 6 months later to ensure virus had not been suppressed by colostral antibodies. In Herds 4 and 5 all calves younger than 3 months at the herd blood test were tested a year later. In Herd 2 young calves were not retested.

\section{Follow up blood tests}

Calves born later than the herd blood test were examined as follows: In Herd 1 all calves born up to 6 months after herd blood test (i.e. 1 year after acute infection) and in Herd 2 all calves born up to 9 months after herd blood test (i.e. 10 months after acute infection) were tested. In Herds 3-5 all calves born up to 1 year after the herd blood test were tested. All samples taken at herd blood test and follow up blood test were examined for virus and antibodies. Most calves born in the follow up period were tested simultaneously at the end 
of the follow up period.

Most of the viraemic animals were retested for virus at least 2 weeks later in order to ensure that they were PI and not acutely infected.

\section{Removal of PI animals}

Most often PI animals were kept until they reached slaughter weight or they were removed earlier if 1 of them showed clinical signs. In Herd 3 a PI animal found at herd blood test was kept more than 1 year after herd blood test in order to immunize remaining seronegative animals. In this herd the seronegative animals were retested to ensure they had seroconverted.

\section{Spot test}

After the last PI or viraemic animal had been removed the herds were left alone for a time period that varied for each herd (this period is shown for each herd in Table 3 as "post PI period". Then the herds were visited again and blood was collected from a spot sample of about 10 animals for antibody analysis. All animals in the sample were born after removal of the last PI animal in the herds. In Herds 25 the animals were 6-18 months old. In Herd 1 they were $2-2 \frac{1}{2}$ years, but in this herd also 5 younger stock were tested.

\section{Herd management}

The farmers were allowed to continue their management policy as usual, i.e. no attempt of systematic control of the infection was made. The farmers were encouraged to either avoid purchase of animals or to have these animals tested. The total number of new introductions from the time of the herd blood test until spot test in the 5 herds were: Herd 1:12, Herd 2:13, Herd 3: 22, Herd 4: 0 and Herd 5: 4. In Herd 2 all new introductions were tested. In Herd 3 all new introductions until 2 years after the
Table 1. Examination of blood from all animals in 5 herds for BVD virus and antibodies.

\begin{tabular}{lccc}
\hline Herd & Virus & \multicolumn{2}{c}{ Virus negative } \\
\cline { 3 - 4 } positive & & $\begin{array}{c}\text { Antibody } \\
\text { negative }\end{array}$ & $\begin{array}{c}\text { Antibody } \\
\text { positive }\end{array}$ \\
\hline 1 & 0 & 5 & 110 \\
2 & 2 & 79 & 152 \\
3 & 6 & 6 & 198 \\
4 & $3^{*}$ & 73 & 38 \\
5 & 10 & 3 & 111 \\
\hline
\end{tabular}

* Two of the 3 virus positive animals in Herd 4 seroconverted later.

herd blood test were tested. The new introductions were most often not tested until they had been in the herds for some time.

In Herd 1, no animals went on summer grazing. In the remaining 4 herds both cows and younger stock went on summer grazing.

\section{Results}

\section{Herd blood tests}

The results of the herd blood test are shown in Table 1. Among the 21 viraemic animals shown in Table 1, 19 were retested for virus isolation. Seventeen animals were also viraemic at the second test whereas 2 animals in

Table 2. Examination for BVD virus and antibodies in calves born during the follow up period after the herd blood test.

\begin{tabular}{|c|c|c|c|c|}
\hline \multirow[b]{2}{*}{$\begin{array}{l}\text { Herd } \\
\text { Number }\end{array}$} & \multirow{2}{*}{$\begin{array}{l}\text { Length of } \\
\text { follow up } \\
\text { period after } \\
\text { herd blood } \\
\text { test (months) }\end{array}$} & \multirow{2}{*}{$\begin{array}{c}\text { Virus } \\
\text { positive }\end{array}$} & \multicolumn{2}{|c|}{ Virus negative } \\
\hline & & & $\begin{array}{l}\text { Antibody } \\
\text { negative }\end{array}$ & $\begin{array}{c}\text { Antibody } \\
\text { positive }\end{array}$ \\
\hline 1 & 6 & 1 & 7 & 38 \\
\hline 2 & 9 & 17 & 2 & 56 \\
\hline 3 & 12 & 2 & 5 & 88 \\
\hline 4 & 12 & 5 & 0 & 28 \\
\hline 5 & 12 & 0 & 3 & 50 \\
\hline
\end{tabular}


Table 3. Time from removal of the last PI animal until sampling of spot test (post PI period) and the number of antibody positive animals in the spot test.

\begin{tabular}{lccc}
\hline & & \multicolumn{2}{c}{ Spot test } \\
\cline { 3 - 4 } $\begin{array}{l}\text { Herd } \\
\text { Number }\end{array}$ & $\begin{array}{c}\text { Post PI } \\
\text { period } \\
\text { (months) }\end{array}$ & $\begin{array}{c}\text { No. animals } \\
\text { tested }\end{array}$ & $\begin{array}{c}\text { No. antibody } \\
\text { positive animals }\end{array}$ \\
\hline 1 & 37 & 10 & 10 \\
2 & 17 & 10 & 9 \\
3 & 24 & 10 & 0 \\
4 & 7 & 10 & 0 \\
5 & 21 & 10 & 0 \\
\hline
\end{tabular}

herd 4 seroconverted. One animal in Herd 3 and 1 animal in Herd 5 were not retested.

In Herds 1, 3, 4 and 5 none of the young animals retested later were viraemic.

In Herd 2 and Herd 4 with many antibody negative animals the PI animals were only 1-2 months old.

\section{Follow up blood tests}

The findings among calves born during the follow up period are shown in Table 2. Among the 25 viraemic animals shown in Table 2, 23 were retested. All retested animals remained viraemic at the second test.

\section{Spot test}

In Table 3 is shown the number of months from removal of the last PI animal until spot test was performed (post PI period). Antibody positive animals were detected in 2 herds. In Herd 1 the additional 5 young animals tested were all antibody positive.

\section{Discussion}

This study investigates the possibility of avoiding further spread of infection after removal of PI animals found by herd blood test and various follow up blood tests. It has been shown that a serological investigation of a small herd sample can predict presence or absence of PI animals with high accuracy (Houe 1992). The study was performed under normal herd conditions i.e. only on few occasions were special precautions taken in order to prevent reintroduction of infection.

At the herd blood test a total of 21 PI animals were found in the 5 herds. During the follow up period another 25 PI animals were found. Especially in Herds 2 and 4 where the PI animals were very young there were many antibody negative animals and therefore many more PI animals were found during the follow up period.

In Herds 1 and 2 there had been recent infection at the time when the spot test was performed. There may be many explanations for this. The follow up period in these 2 herds was shorter than in Herds 3-5. In Herds 1 and 2 all animals born up to 12 and 10 months after the demonstration of acute infection were tested. But, as the acute infection may continue for some months in a herd, PI animals could have been born after the follow up period in these 2 herds. Further, in Herd 1, purchased animals were not tested. In Herd 2, young animals were not retested later. At the herd blood test a pair of twins of only 5 weeks were PI. Therefore, there could probably have been younger PI animals in which the viraemia had been suppressed by colostral antibodies. Colostral antibodies have been shown to suppress viraemia in PI animals until the first 8 weeks of life depending on the initial titer (Meyling \& Jensen 1988, Palfi et al. 1993). Finally, it remains to be clarified whether antibody positive animals can be intermittent virus excretors.

In Herds 3-5 where the follow up period followed 12 months after herd blood test, it seemed that the infection had ceased. Although the infection had ceased in these 3 herds, a 12 months' follow up period may not be enough on all occasions. In Table 2 it can 
be seen that there may still be few antibody negative animals. If in early pregnancy, infection of these animals will give rise to more PI animals. Therefore, the follow up period should be longer among calves born by dams that were antibody negative at the herd blood test or the follow up should include previously seronegative animals either to be sure that they have seroconverted before breeding as in Herd 3 or that they do not seroconvert later. Thus, it seems possible to stop the spread of infection in the herds if proper follow up is made. The next problem is how to avoid reinfection. This seems to be a very frequent phenomenon (Houe \& Palfi 1993). Actually, the number of infections in the herds in this study were fewer than in herds previously without PI animals. Among 9 herds previously without PI animals, serocoversions occurred in 8 of the herds within a 3 years period (Houe \& Palfi 1993). The infection may be introduced easier to a herd with low immunity compared to a herd where most animals are antibody positive.

\section{Acknowledgement}

This study was made with support from the Danish Agricultural and Veterinary Research Council.

\section{References}

Bolin SR: Control of bovine virus diarrhoea virus. Rev. sci. tech. Off. int. Epiz. 1990, 9, 163-171.

Bolin SR, McClurkin AW, Cutlip RC, Coria MF: Severe clinical disease induced in cattle persistently infected with noncytopathic bovine viral diarrhea virus by superinfection with cytopathic bovine viral diarrhea virus. Amer. J. vet. Res. 1985, 46, 573-576.

Brownlie J, Clarke MC, Howard CJ: Experimental production of fatal mucosal disease in cattle. Vet. Rec. 1984, 114, 535-536.

Coria MF, McClurkin AW: Specific immune tolerance in an apparently healthy bull persistently infected with bovine viral diarrhea virus. J. Amer. vet. med. Ass. 1978, 172, 449-451.

Done JT, Terlecki S, Richardson C, Harkness JW,
Sands JJ, Patterson DSP, Sweasey D, Shaw IG, Winkler CE, Duffel SJ: Bovine virus diarrhoeamucosal disease virus: Pathogenicity for the fetal calf following maternal infection. Vet. Rec. 1980, 106, 473-479.

Harkness JW: The control of bovine virus diarrhoea virus infection. Annls. Rech. vét. 1987, 18, 167174.

Houe $H$ : Serological analysis of a small herd sample to predict presence or absence of animals persistently infected with bovine virus diarrhoea virus (BVDV) in dairy herds. Res. Vet. Sci. 1992, 53, 320-323.

Houe H, Meyling A: Prevalence of bovine virus diarrhoea (BVD) in 19 Danish dairy herds and estimation of incidence of infection in early pregnancy. Prev. Vet. Med. 1991, 11, 9-16.

Houe H, Palfi V: Estimation of herd incidence of infection with bovine virus diarrhoea virus (BVDV) in herds previously without animals persistently infected with BVDV. Acta vet. scand. 1993, 34, 133-137.

McClurkin AW, Littledike ET, Cutlip RC, Frank GH, Coria MF, Bolin SR: Production of Cattle Immunotolerant to Bovine Viral Diarrhea Virus. Can. J. Comp. Med. 1984, 48, 156-161.

Meyling A: Detection of BVD virus in viraemic cattle by an indirect immunoperoxidase technique. In: McNulty MS, MacFerran JB (eds.): Recent advances in virus diagnosis. Martinus Nijhoff Publishers, Boston, 1984, 37-46.

Meyling A, Houe H, Jensen AM: Epidemiology of bovine virus diarrhoea virus. Rev. sci. tech. Off. int. Epiz. 1990, 9, 75-93.

Meyling A, Jensen AM: Transmission of bovine virus diarrhoea virus (BVDV) by artificial insemination (AI) with semen from a persistently-infected bull. Vet. Microbiol. 1988, 17, 97-105.

Palfi V, Houe H, Philipsen JS: Studies on the decline of bovine virus diarrhoea virus (BVDV) maternal antibodies and detectability of BVDV in persistently infected calves. Acta vet. scand. 1993, 34, 105-108.

$Q$ vist $P$ : An enzyme-linked immunosorbent assay for the detection of serum antibodies to bovine virus diarrhoea virus. Acta vet. scand. Submitted.

Roeder P L, Drew TW: Mucosal disease of cattle: A late sequel to fetal infection. Vet. Rec. 1984, 114, 309-313.

Roeder PL, Harkness JW: BVD virus infection: Prospects for control. Vet. Rec. 1986, 118, 143-147. 
Roeder PL, Jeffrey M, Cranwell MP: Pestivirus fetopathogenicity in cattle: Changing sequelae with fetal maturation. Vet. Rec. 1986, 118, 44-48.

\section{Sammendrag}

Fors $\varnothing g$ på at hindre fortsat smittespredning med bovin virus diarré virus $(B V D V)$ i 5 danske malkekvagsbesatninger hvori BVDV var blevet påvist.

I 5 besætninger, hvor bovin virusdiarré virus (BVDV) tidligere var blevet påvist, blev blodprøver fra samtlige dyr undersøgt for virus og antistof. Opfølgende blodprøver blev udtaget fra kalve, som fødtes senere i besætningerne. I én besætning omfattede de opfølgende prøver alle kalve, som blev født indtil 6 måneder efter blodprøvning af hele besætningen, i én besætning alle kalve, som blev født indtil 9 måneder efter blodprøvning af hele besætningen og i 3 besætninger omfattede de opfølgende prøver alle kalve, som blev født indtil 12 måneder efter blodprøvning af hele besætningen. Persistent inficerede dyr (PI-dyr) blev fjernet. Nogen tid senere blev blodprøver fra en stikprøve på 10 dyr i hver besætning unders $\emptyset \mathrm{gt}$ for antistoffer. Samtlige dyr i stikprøverne var født efter fjernelse af PIdyrene.

Ved besætningsblodprøverne påvistes ialt 21 PI-dyr. Ved de opfølgende prøver påvistes yderligere 25 PIdyr.

Blandt dyrene i de senere udtagne stikprøver fandtes antistofreagenter i de 2 besætninger, hvor de opfølgende prøver blev taget indtil henholdsvis 6 og 9 måneder efter blodprøvning af hele besætningen. I de 3 besætninger, hvor alle kalve født indtil 12 måneder efter besætningsblodprøven blev testet, var der ingen antistofreagenter i stikprøven.

Det synes muligt at stoppe smittespredning med BVDV, såfremt samtlige dyr i besætningen samt alle dyr, som fødes det efterfølgende år, testes og påviste PI-dyr efterfølgende fjernes.

(Received August 27, 1992; accepted December 18, 1992).

Reprints may be requested from: H. Houe, Department of Clinical Studies, Royal Veterinary and Agricultural University, Bülowsvej 13, DK-1870 Frederiksberg C, Denmark. 